Zabytkoznawstwo i Konserwatorstwo XXXVIII, Toruń 2010

Elżbieta Basiul

Uniwersytet Mikołaja Kopernika w Toruniu

\title{
Badania konserwatorskie malowideł ściennych w kościele parafialnym pw. św. Szymona i św. Judy Tadeusza w Kosieczynie
}

$\mathrm{W}$ kościele parafialnym pw. św. Szymona i św. Judy Tadeusza w Kosieczynie przeprowadzono w ubiegłym roku badania konserwatorskie pierwotnych polichromii ściennych występujących we wnętrzu budowli. $\mathrm{W}$ ich ramach wykonano odkrywki pierwotnej polichromii oraz dokonano kompleksowej analizy odsłoniętych malowideł w zakresie badań nieniszczących. Z pobranych próbek warstw malarskich wykonano naszlify i podjęto badania przekrojów poprzecznych technikami mikroskopowymi. W celu określenia rodzaju spoiwa występującego $\mathrm{w}$ pierwotnych polichromiach zrealizowano badania chromatograficzne. Analiza dekoracji wewnętrznych ścian świątyni była kolejnym etapem prac badawczych, które poprzedzaty m.in. badania dendrochronologiczne. Badania polichromii wewnątrz świątyni doprowadziły do odkrycia pierwotnych malowideł wystepujących bezpośrednio na drewnianych belkach.

Kościół parafialny pw. św. Szymona i św. Judy Tadeusza w Kosieczynie (il. 1) jest budowla drewniana, jednonawowa, zbudowana na planie prostokạta, z prostokątnym prezbiterium, do którego nieco później dobudowano zakrystię. Świątynię zamyka od góry sklepienie kolebkowe. Kościół został zbudowany z drewnianych belek. W ostatnim okresie zrekonstruowano pierwotne pokrycie dachowe w typie gontu. W latach 80 . XX wieku ściany wewnętrzne kościoła pokryto deskami (il. 2). Analiza dendrochronologiczna 
przeprowadzona w 2006 roku pozwoliła określić czas budowy kościoła na przełom XIV i XV wieku (nawa i prezbiterium - ok. 1388/1389 r., więźba dachowa - 1407/1416 r., wieża - 1431 r.) ${ }^{1}$.

Powierzchnie ścian wewnętrznych mają ślady pierwotnych średniowiecznych polichromii pokrytych później warstwą pobiały, a następnie grubą warstwą gliny z wypełniaczem roślinnym (słoma). Powierzchnia gliny, odpowiednio ukształtowana (widoczne są otwory - ślady narzędzia do ubijania gliny narzuconej na powierzchnię ściany), została wyrównana cienką warstwą wapienno-piaskowej zaprawy, na którą nałożono wapienną pobiałę. W okresach późniejszych ściany kościoła pokryto kilkoma barwnymi warstwami farb klejowych (il. 8). Pierwsza z nich w kolorze szarobłękitnobiałym reprezentuje malarstwo szablonowe typowe dla przełomu XIX i XX wieku (il. 3-9). Następne warstwy w kolorze żółtym i różowym pochodzą z drugiej połowy XX wieku.

W części nawowej opracowanie malarskie było bardzo ograniczone i sprowadzało się do dwóch stref barwnych: dolna w kolorze błękitnym (błękit organiczny - indygo?), górna w kolorze białym, zawierająca krede, biel ołowiową (il. 10). Na polu białym występowały kolorowe wzory w formie roślinnych ornamentów, trudne do określenia z powodu śladowych ilości pierwotnej polichromii. Drobne skupiska polichromii wskazują na farbę czarną (czerń weglowa), szarą (biel ołowiowa, czerń weglowa, kreda), jasnoczerwoną (minia), ciemnoczerwoną (czerwień żelazowa), zieloną (malachit), błękitną (smalta, indygo?) (il. 11-14). W prezbiterium zastosowano dwupasmowe rozwiązanie, podobnie jak w nawie kościoła, z tą różnica, że w prezbiterium dolna, błękitna część została podzielona na pionowe pasy. Każdy z nich wypełniono schematycznymi ornamentami roślinnymi w kolorze jasnej czerwieni (il. 4). Wszystkie polichromie zostały położone na cienkiej białej warstwie zawierającej kredę i klej. Spoiwem występującym w warstwach polichromii jest kazeina, której źródłem było mleko zwierzęce (il. 15).

Obserwacja odsłoniętych powierzchni belek wskazuje na to, że przed położeniem warstwy gliny powierzchnię drewna intensywnie nasiekano

1 T. Ważny, Analiza dendrochronologiczna kościoła w Kosieczynie, „Lubuskie Materiały Konserwatorskie”, Zielona Góra 2007, t. 4 (2006-2007), s. 42. 
ostrym narzędziem (siekierką - widoczne ślady ukośnych nacięć), a w wielu miejscach farbe zdrapywano (il. 10). Dodatkowo w lico ścian wbito rzędy drewnianych kołków, które gwarantowały dobrą przyczepność warstwy gliny (il. 4, 6). Odsłonięta polichromia zachowała się w ilościach szczątkowych. Jedynie na ścianie południowej prezbiterium można stwierdzić charakter i stylistykę dekoracji ornamentalnej.

Wykonane odkrywki wskazują na miejscowy atak mikrobiologiczny drewna zabytkowego (owady), głównie w dolnych partiach ścian osłabionych wcześniejszym zawilgoceniem. Badania termowizyjne wskazały na miejsca o podwyższonej wilgotności, które mogą pokrywać się z partiami osłabionymi przez czynniki biologiczne (il. 5). Nie stwierdzono poważnych zagrożeń mykologicznych.

Otrzymane wyniki badań są niezwykle ważne w ustalaniu chronologii całej budowli. Stanowią część komplementarnych analiz, które pozwalają umiejscowić kościól św. Szymona i św. Judy Tadeusza wśród najstarszych kościołów w Polsce. Na podstawie przeprowadzonych badań techniki i technologii malowideł odkrytych we wnętrzu świątyni można je wstępnie datować na XVI-XVII wiek. Słaby stan zachowania pierwotnej polichromii utrudnia powzięcie decyzji o zdjęciu wtórnej warstwy gliny z powierzchni ścian kościoła. 


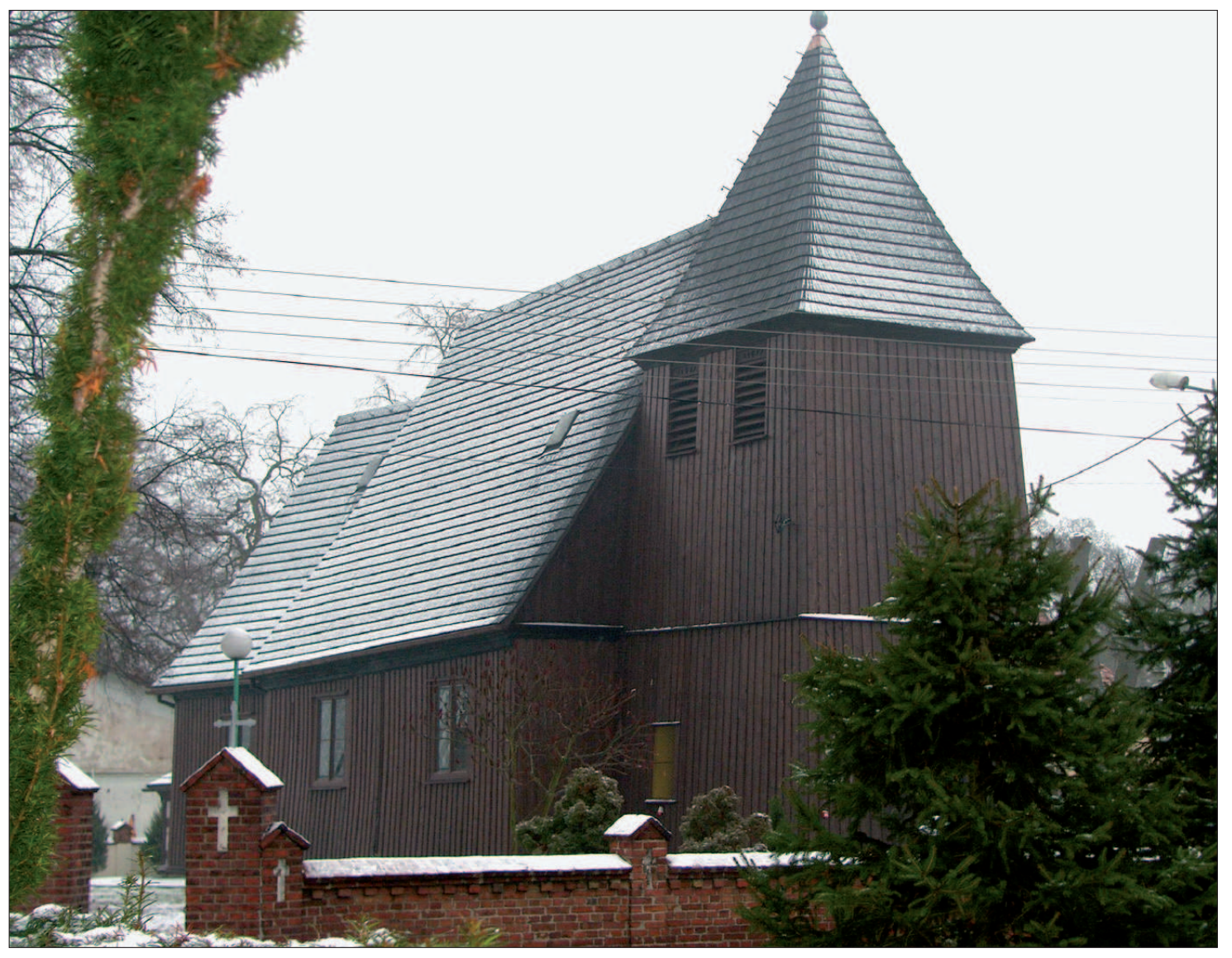

Il. 1. Kościół parafialny w Kosieczynie - widok kościoła po wykonaniu prac remontowych w 2008 r. (fot. ks. A. Przybysz) 


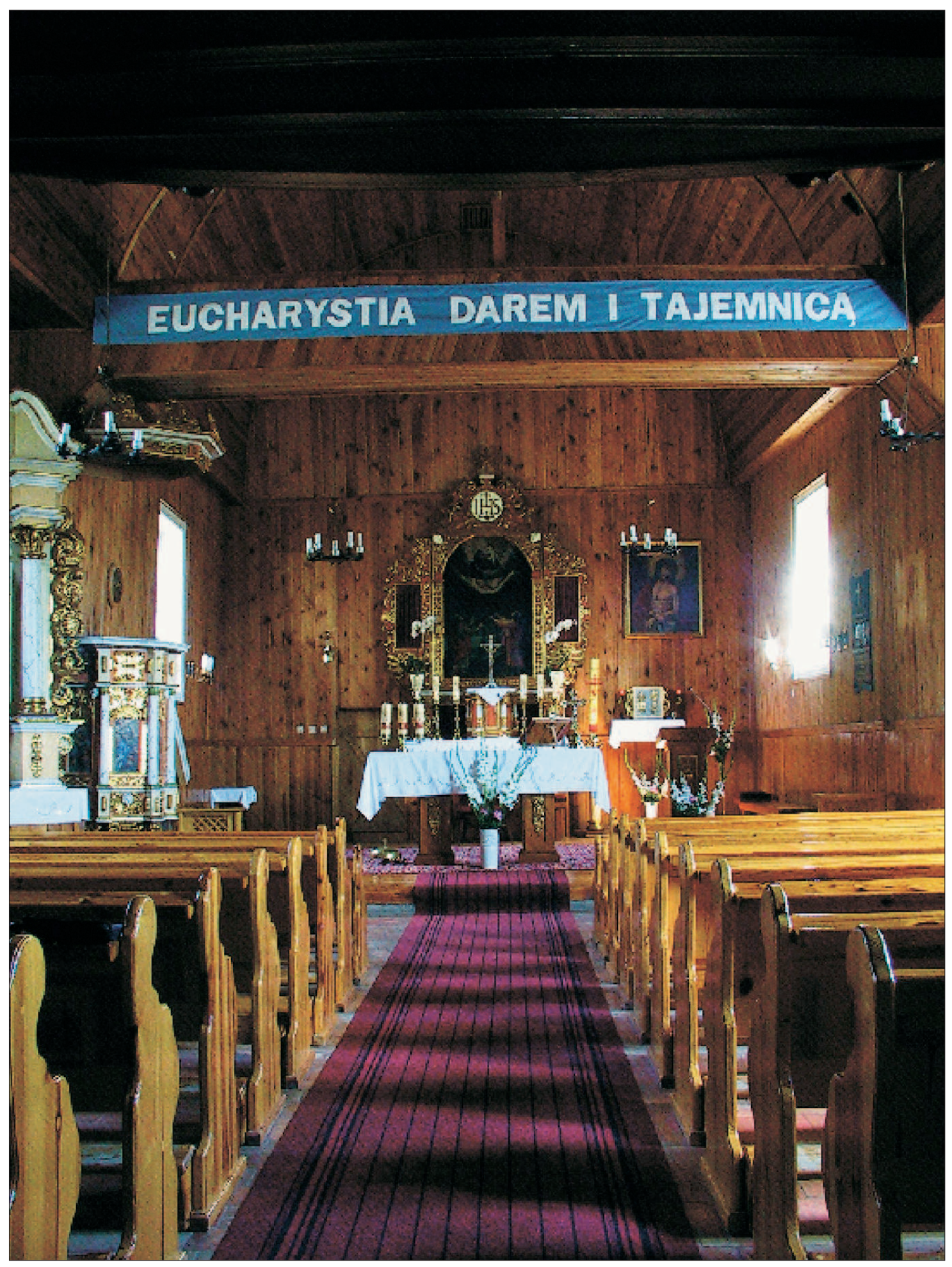

Il. 2. Kościół parafialny w Kosieczynie - widok na prezbiterium przed rozpoczęciem badań (fot. A. Cupa) 


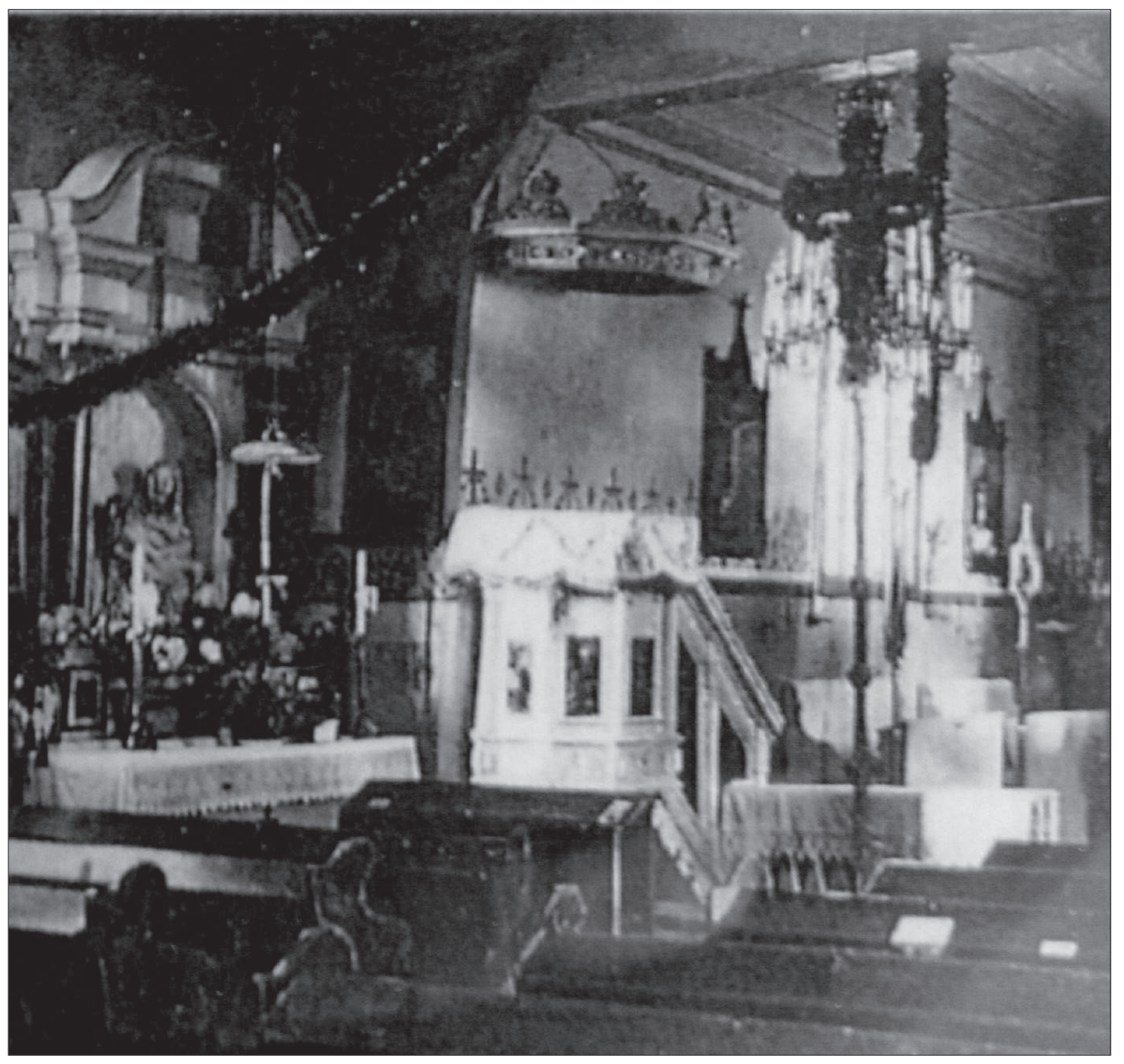

Il. 3. Kościół w Kosieczynie - fotografia wnętrza kościoła z lat 30. (?) XX w. Widoczne szablonowe dekoracje ornamentalne na poziomie lamperii (fot. $\mathrm{z}$ archiwum parafii) 
a)

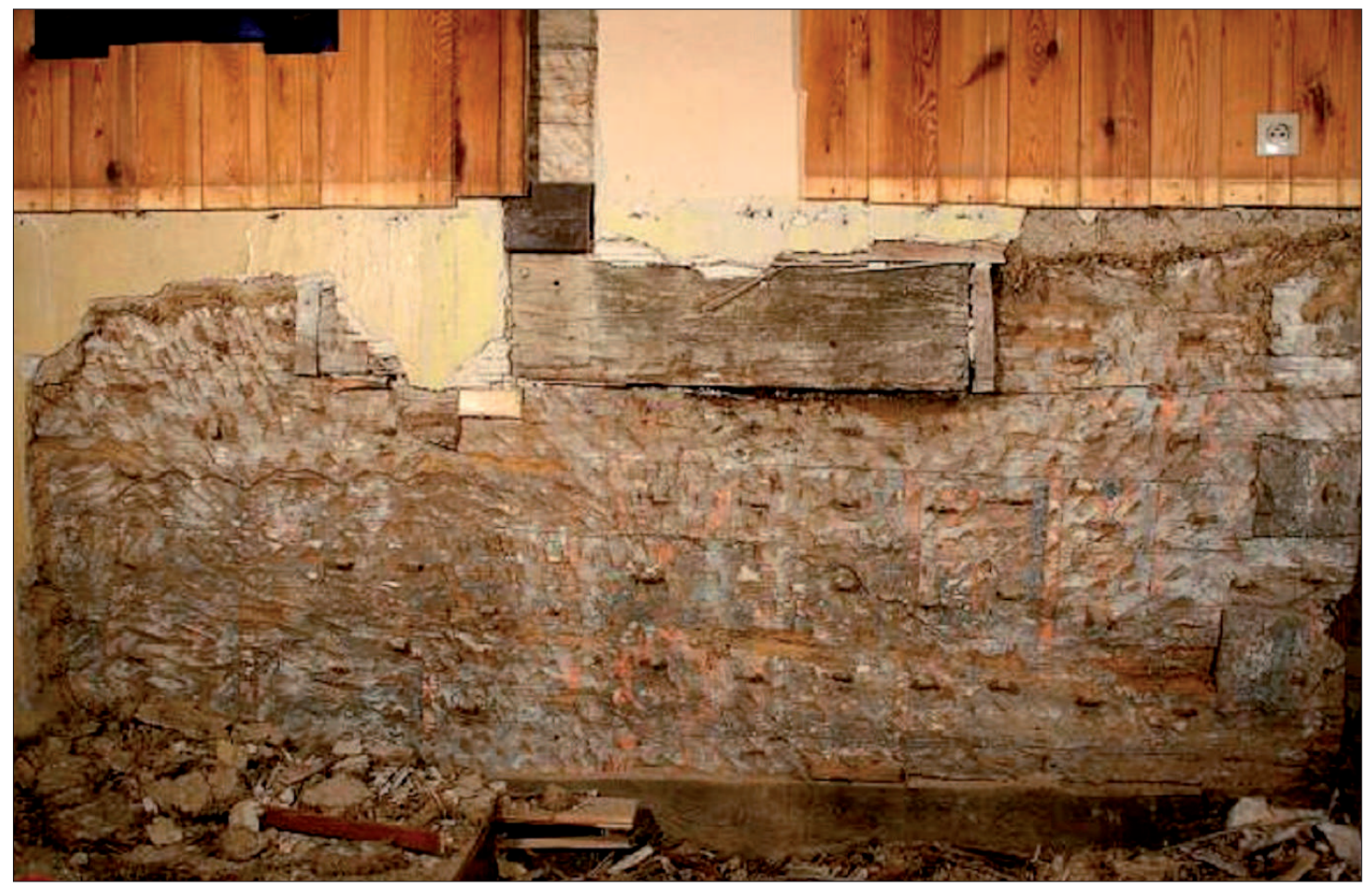

b)

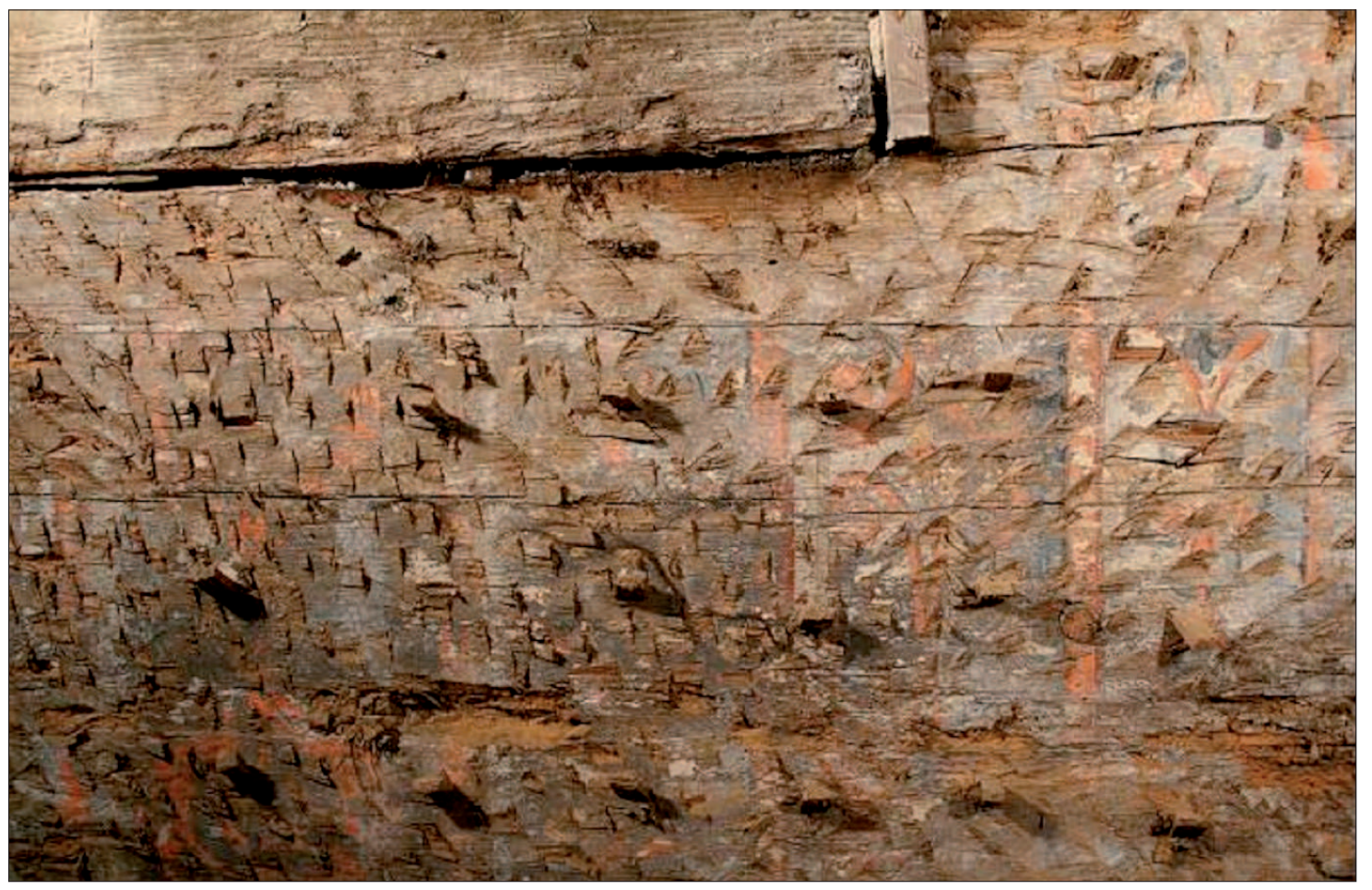

Il. 4a, b. Kościół w Kosieczynie - odsłonięcie pierwotnej polichromii na południowej ścianie prezbiterium kościoła (fot. A. Cupa) 


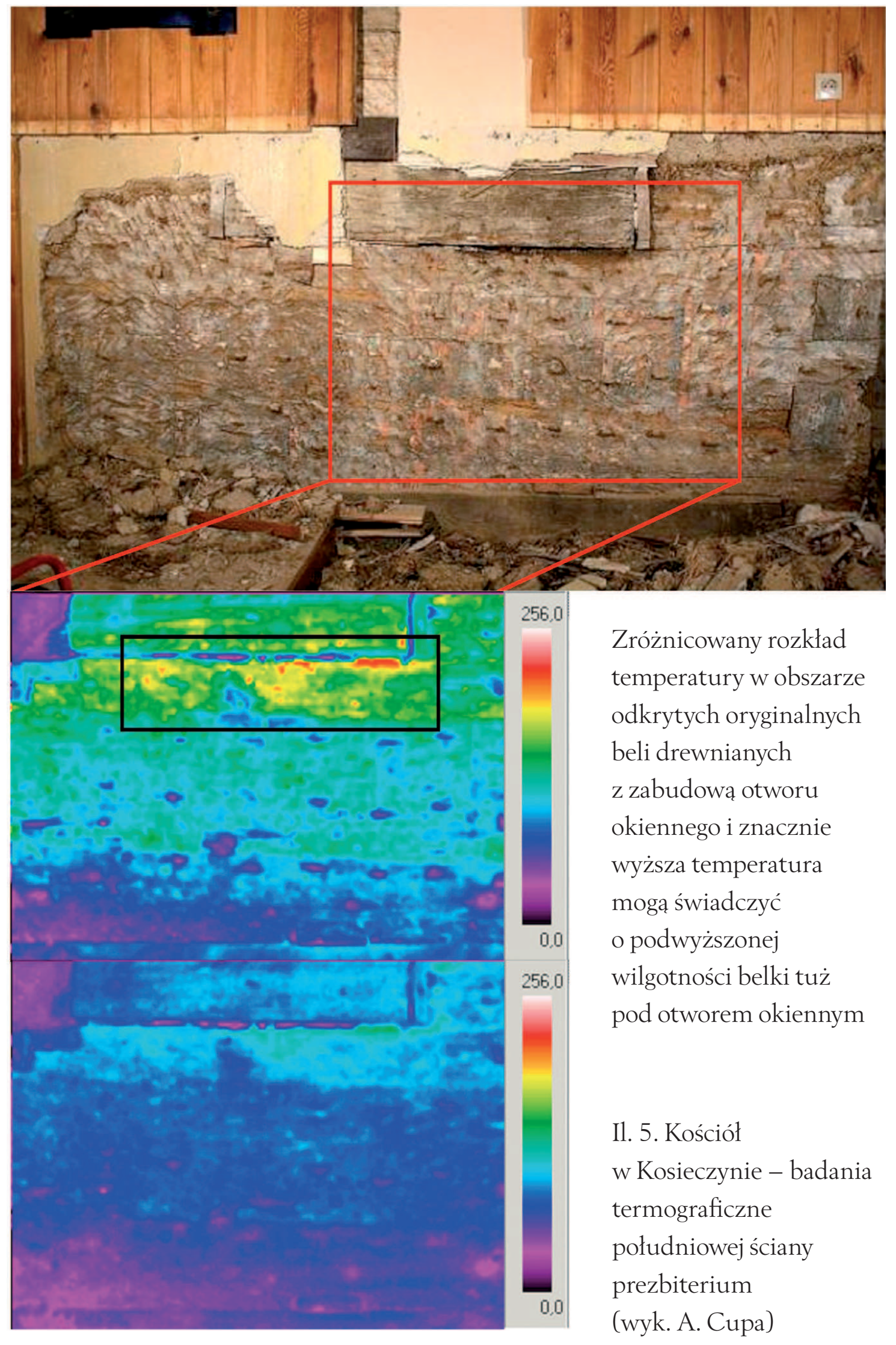


a)

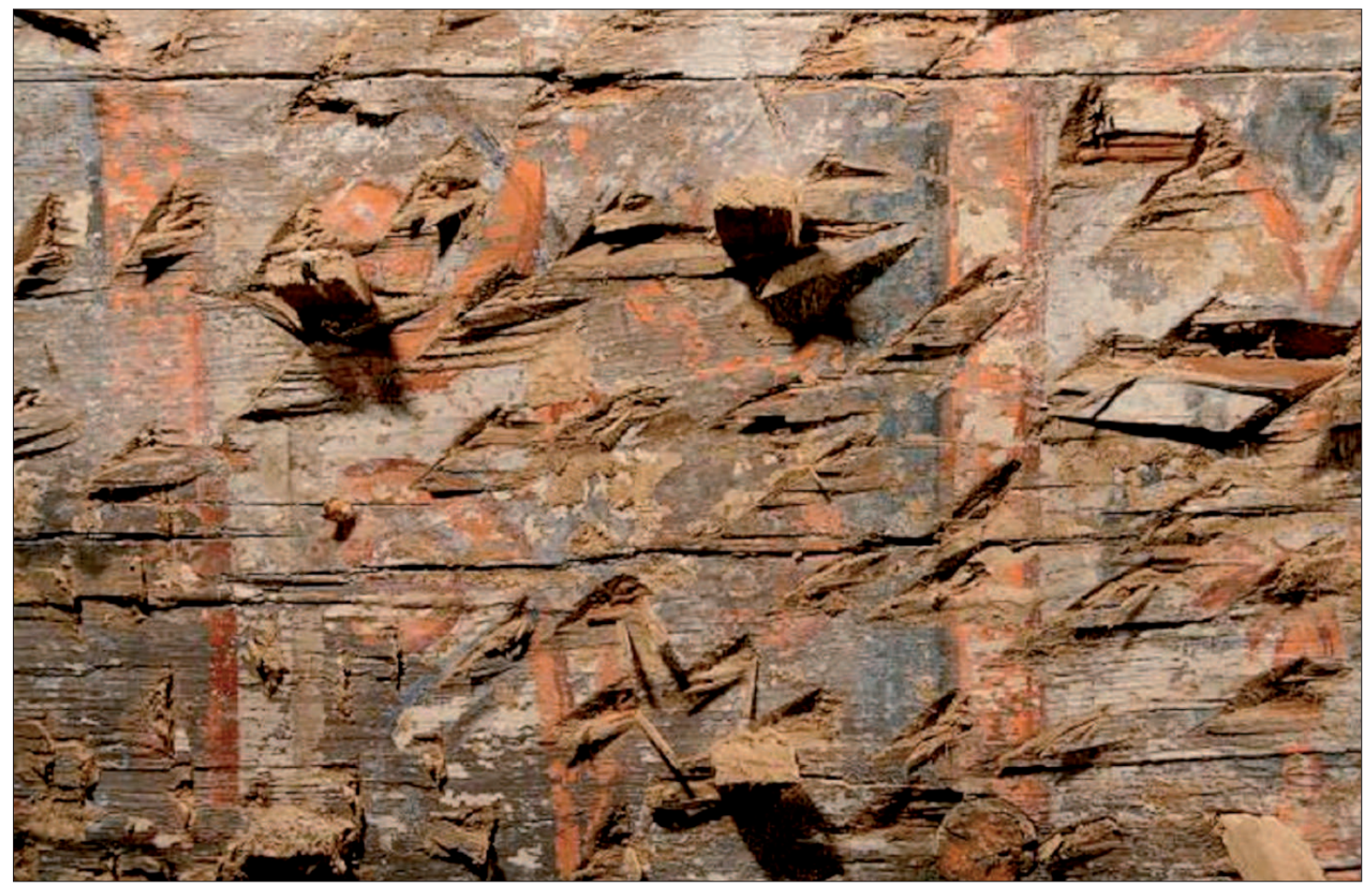

b)

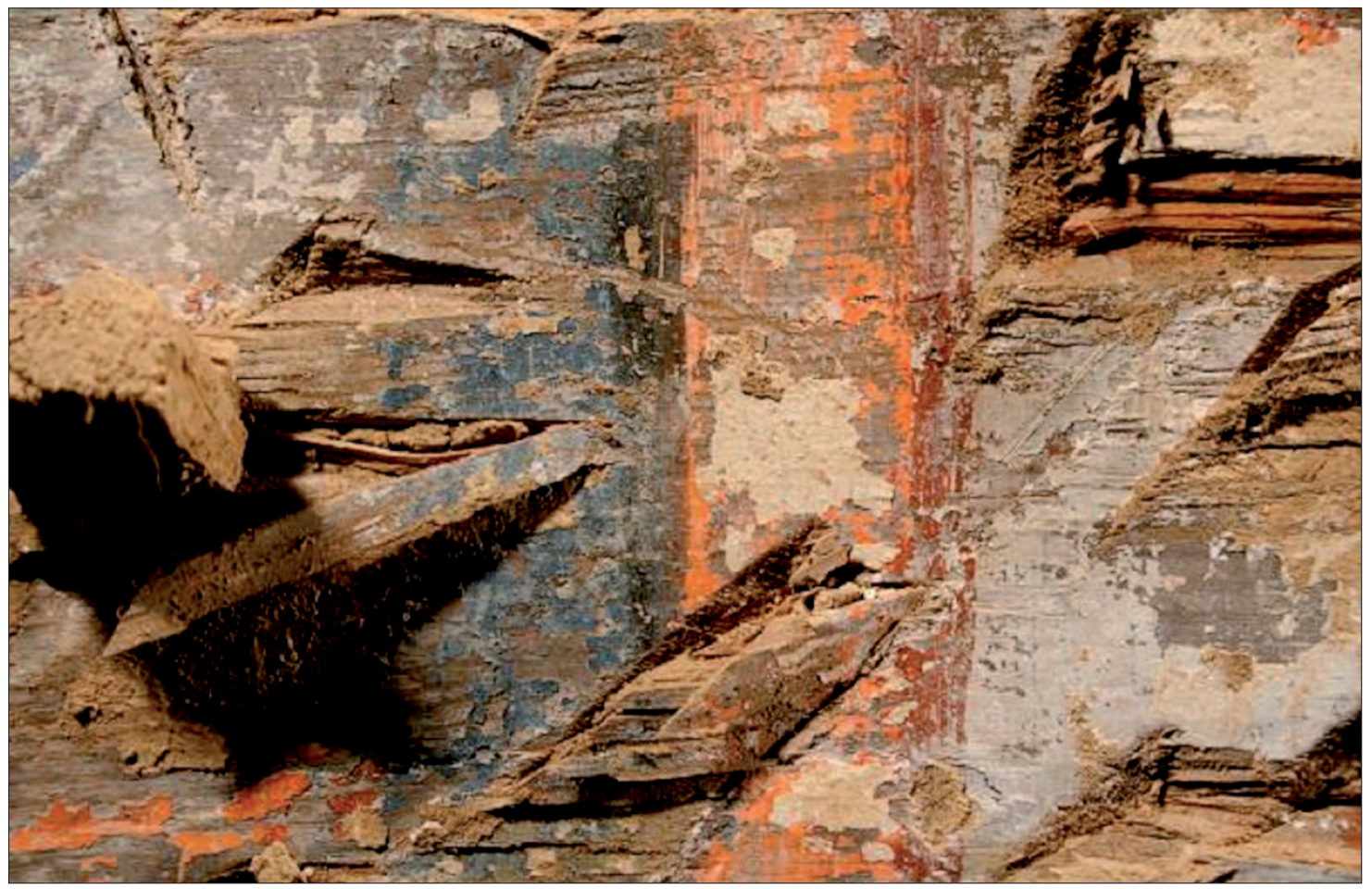

Il. 6a, b. Kościół w Kosieczynie - fragment pierwotnej polichromii na południowej ścianie prezbiterium kościoła (fot. A. Cupa) 


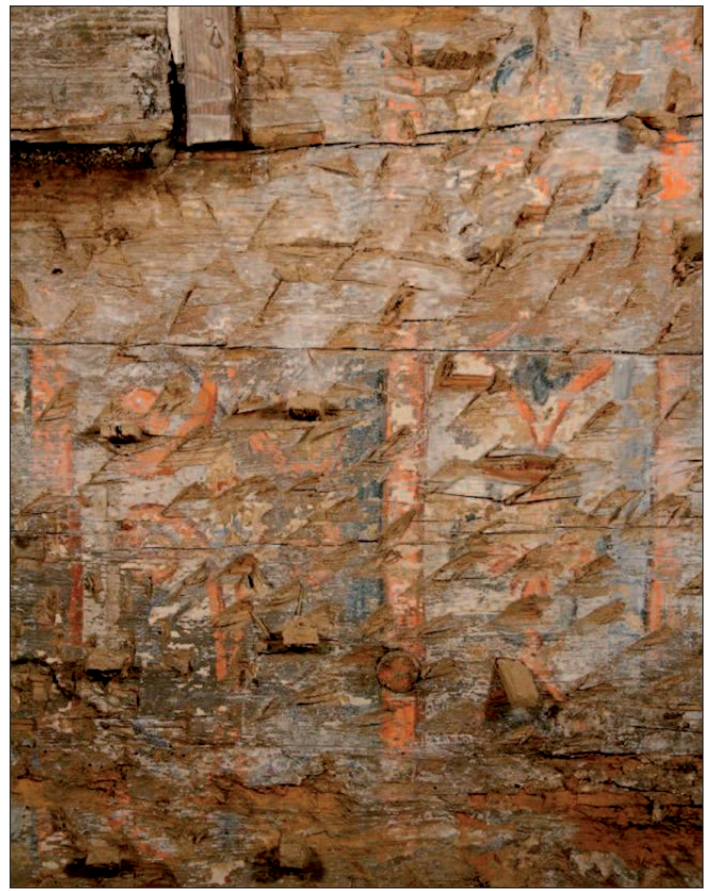

a) zdjęcie w zakresie widzialnym

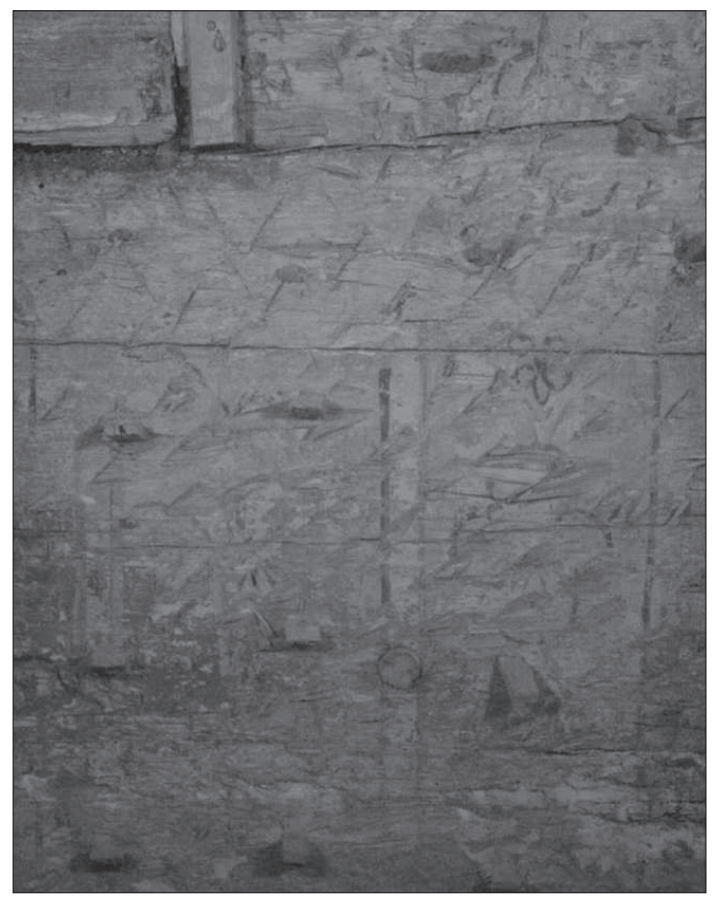

c) reflektografia w podczerwieni

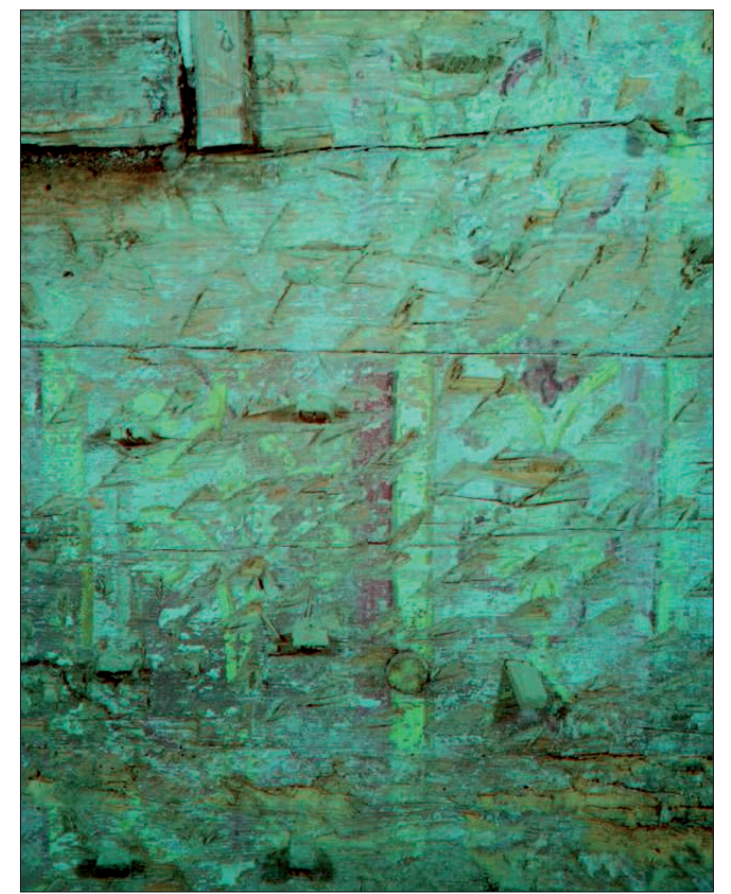

b) zdjęcie kolorowej podczerwieni

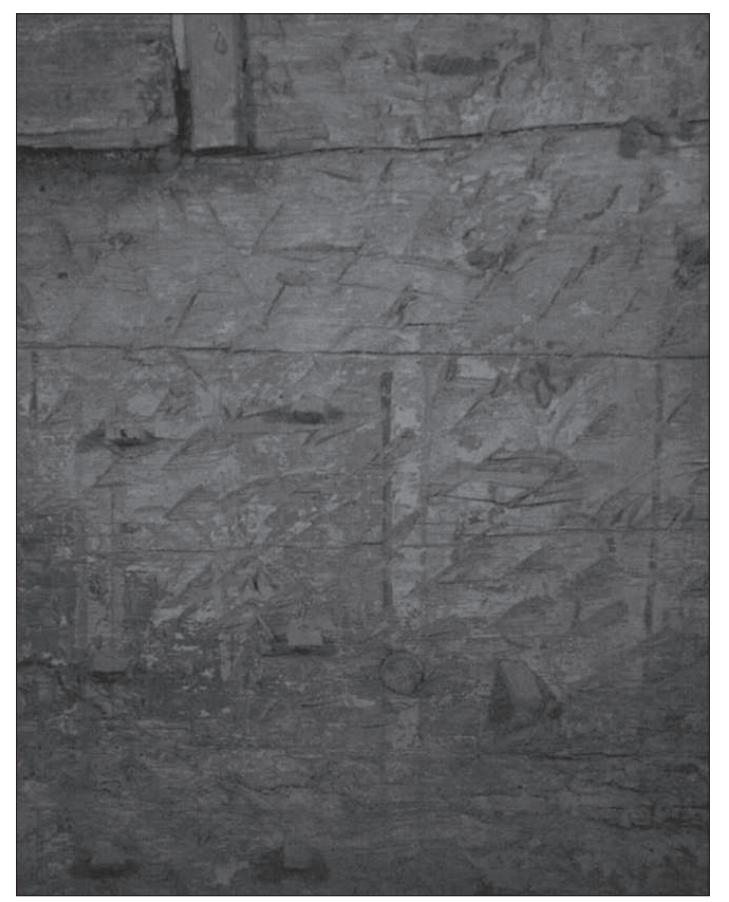

d) reflektografia w ultrafiolecie

Il. 7a-d. Kościół w Kosieczynie - badanie polichromii na ścianie południowej prezbiterium $\mathrm{w}$ różnych zakresach promieniowania elektromagnetycznego (fot. A. Cupa) 


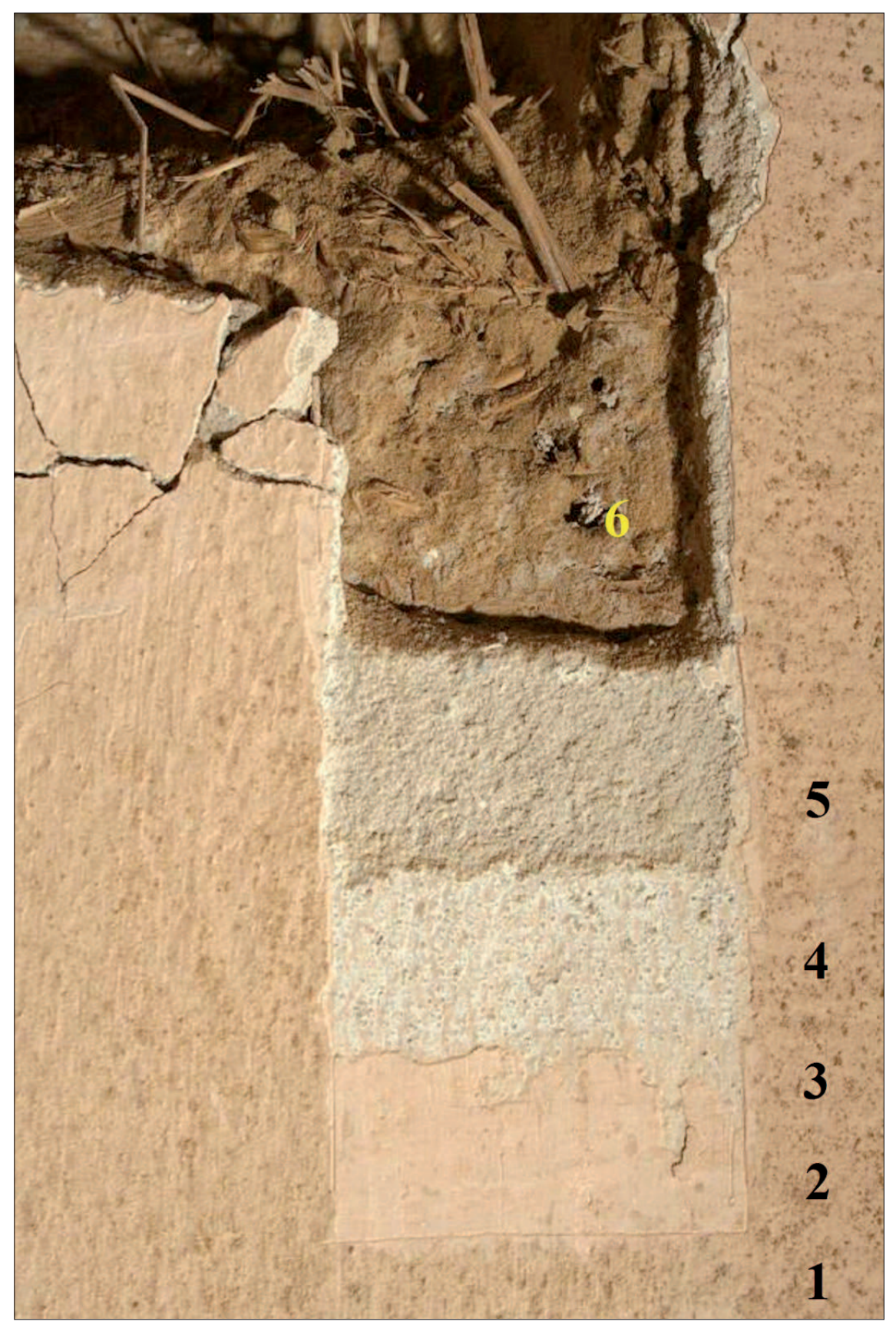

Il. 8. Odkrywka wykonana w wierzchniej warstwie polichromii na ścianie południowej prezbiterium (fot. A. Cupa):

1 - warstwa malarska szaroróżowa

2 - warstwa malarska różowa

3 - warstwa malarska różowa

4 - warstwa malarska biała - pobiała

5 - tynk wapienny

6 - warstwa tynku glinianego z wypełniaczem - słoma 


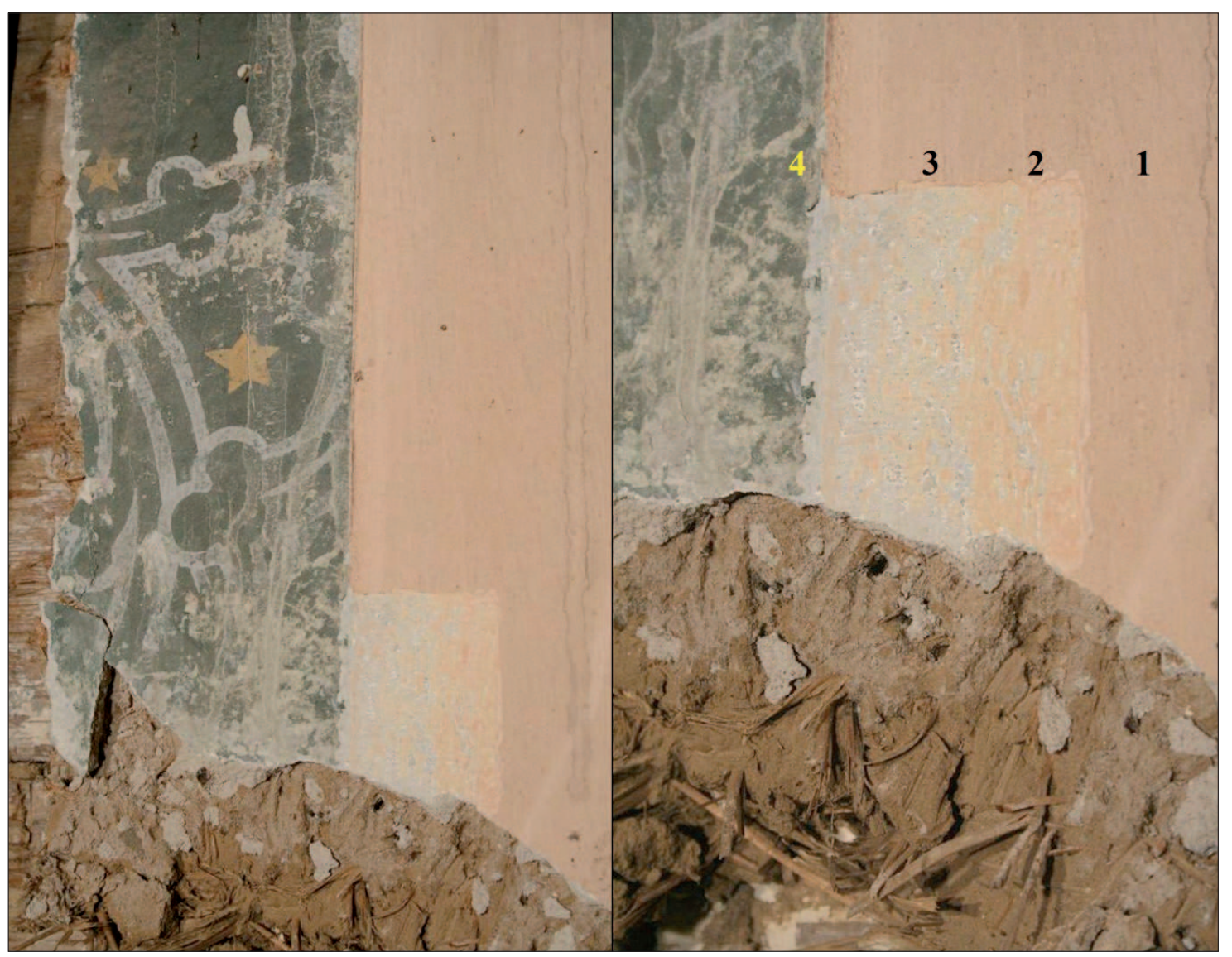

Il. 9. Kościół w Kosieczynie - odkrywka na ścianie nawy południowej - widoczny ornament z przełomu XIX i XX w. (fot. A. Cupa):

1 - warstwa malarska szaroróżowa

2 - warstwa malarska różowa

3 - warstwa malarska jasnoszara

4 - warstwa szara z ornamentem 


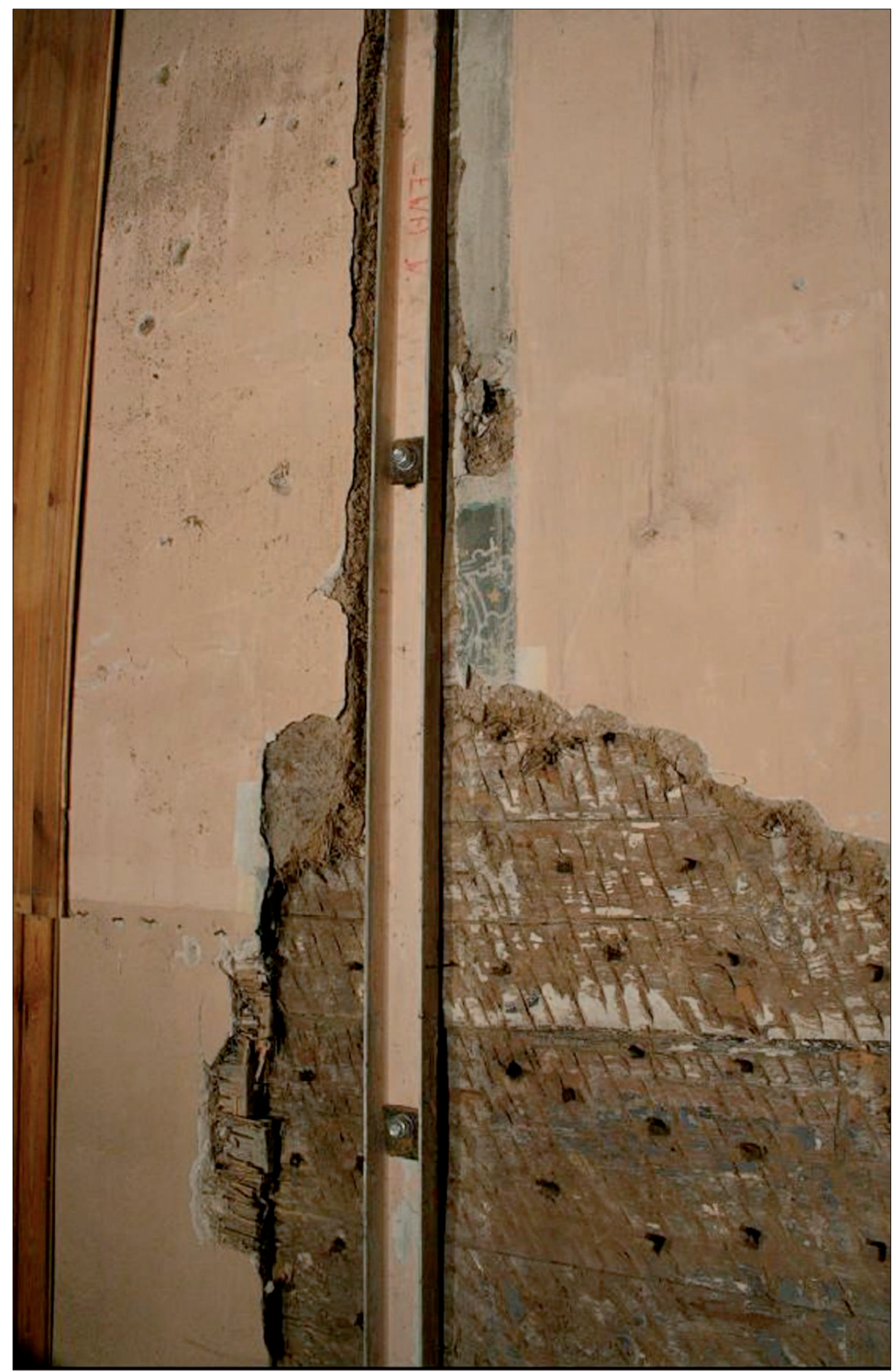

Il. 10. Kościół w Kosieczynie - odkrywka na południowej ścianie nawy - widoczne pierwotne opracowanie barwne ściany: błękit w partii lamperii, biel w części górnej (fot. A. Cupa) 


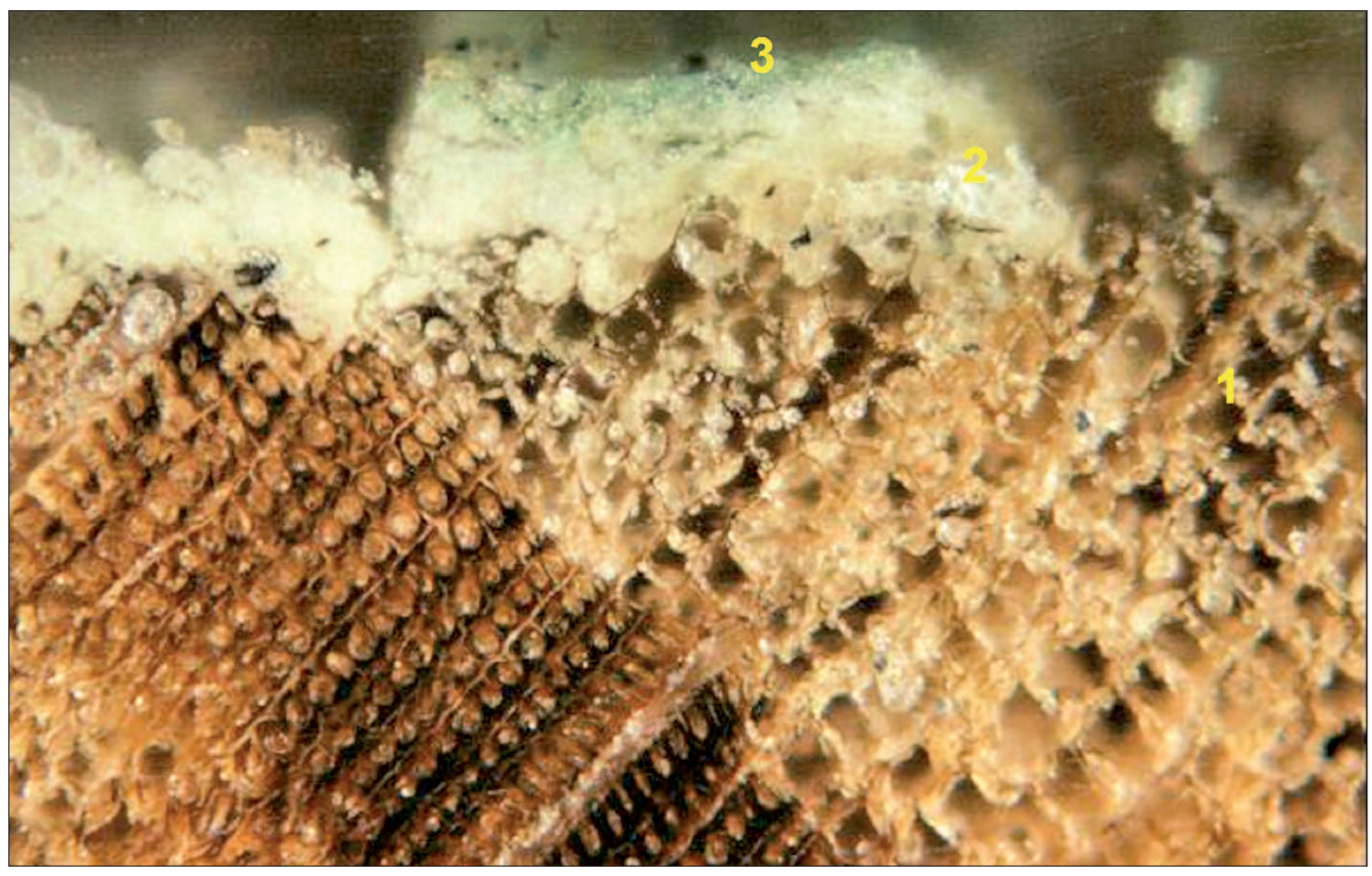

Il. 11. Kościół w Kosieczynie, prezbiterium, ściana południowa - próbka nr 9', zieleń (fot. A. Cupa)

\begin{tabular}{|c|l|l|c|}
\hline $\mathbf{N r}$ & \multicolumn{1}{|c|}{ Warstwa } & \multicolumn{1}{|c|}{ Skład chemiczny } & Rodzaj spoiwa \\
\hline 3 & Zielona & $\begin{array}{l}\text { zieleń miedziowa - malachit } \mathrm{Cu}(\mathrm{OH})_{2}{ }^{*} \\
\mathrm{CuCO}_{3} \text {, ziemia zielona (?) }\end{array}$ & klejowe - kazeina \\
\hline 2 & Biała & kreda $\mathrm{CaCO}_{3}$ & klejowe - kazeina \\
\hline 1 & Drewno & - & - \\
\hline
\end{tabular}

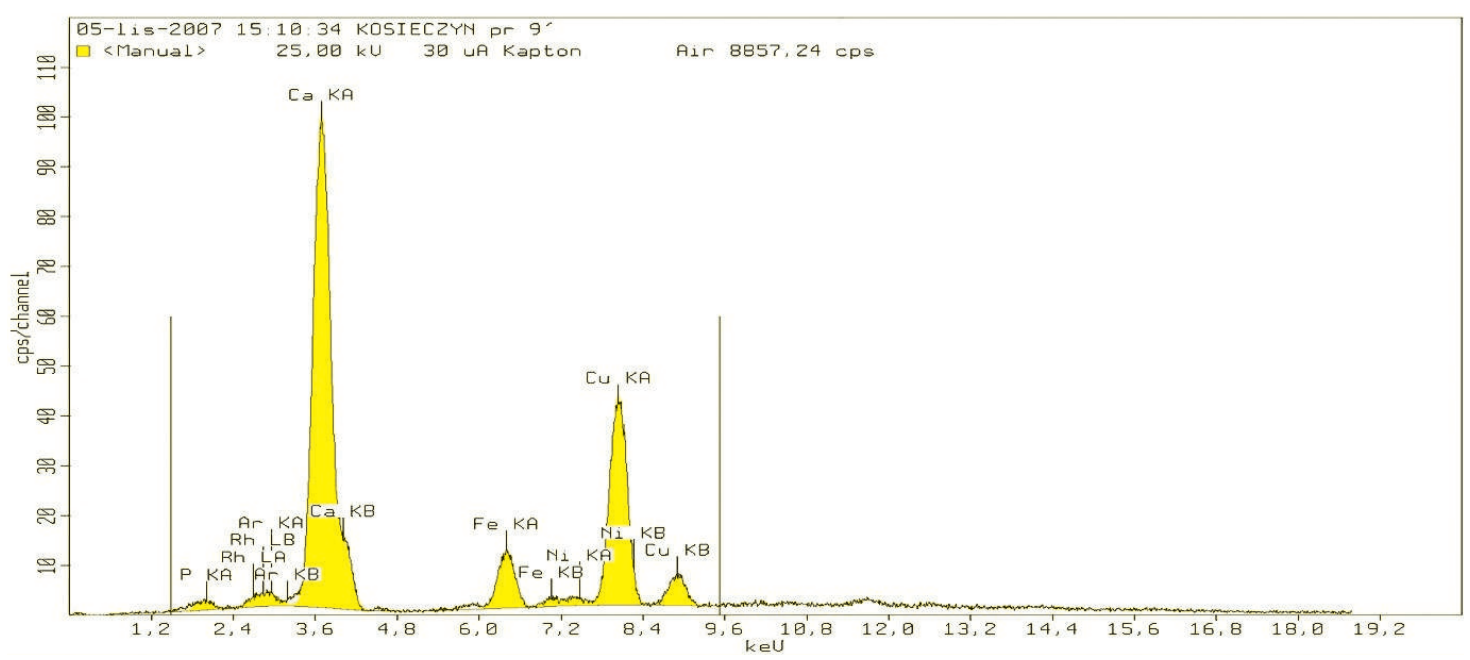

Il. 12. Rentgenowska analiza fluorescencyjna próbki 9': Ca, Cu, Fe, P 


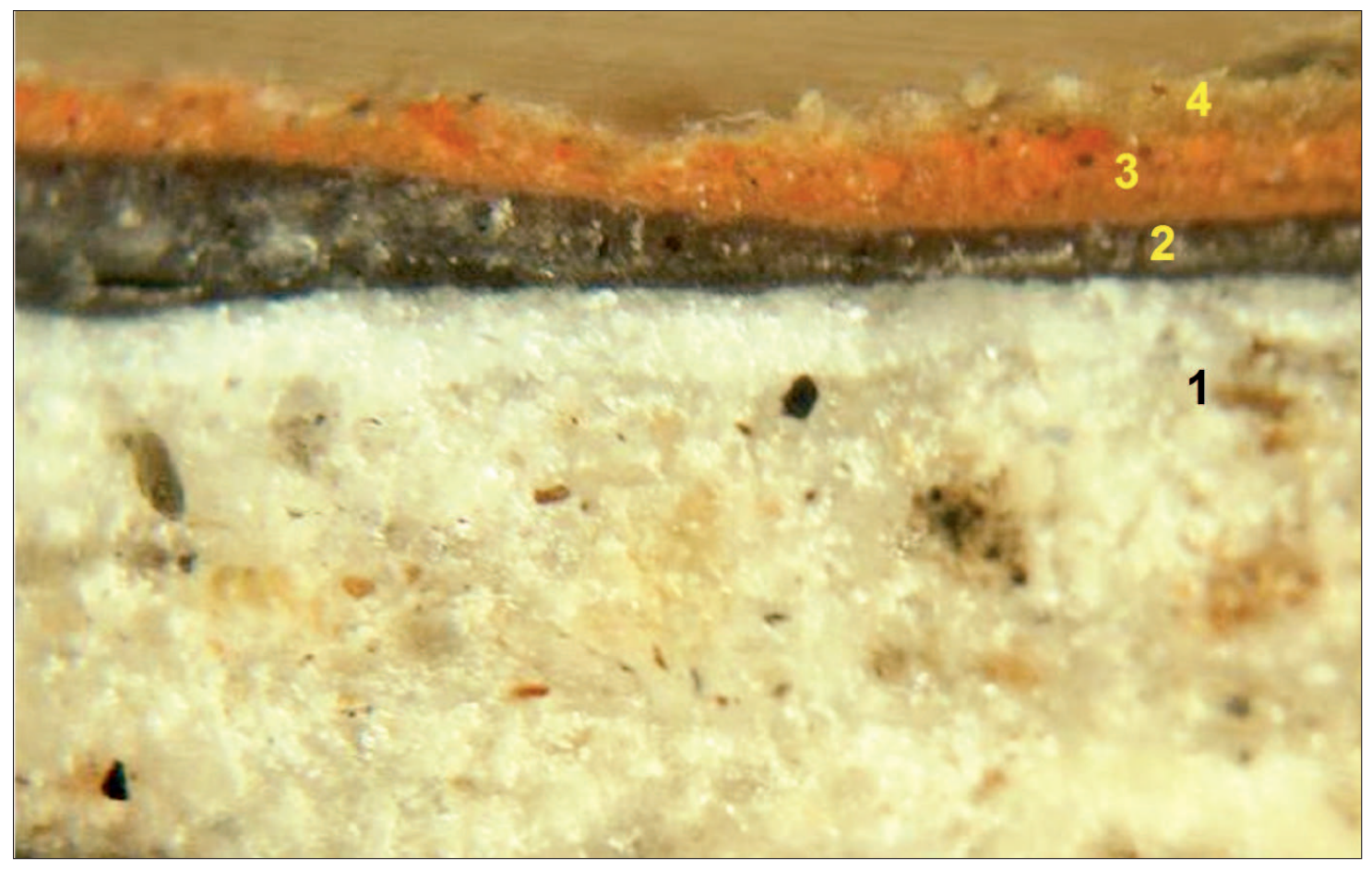

Il. 13. Kościół w Kosieczynie, prezbiterium, ściana południowa - próbka nr 15', ciemna czerwień (fot. A. Cupa)

\begin{tabular}{|c|l|l|c|}
\hline $\mathrm{Nr}$ & Warstwa & \multicolumn{1}{|c|}{ Skład chemiczny } & Rodzaj spoiwa \\
\hline 4 & Ugrowa & czerwień żelazowa $\mathrm{Fe}_{2} \mathrm{O}_{3}$, ugier?, kreda $\mathrm{CaCO}_{3}$ & klejowe (kazeina) \\
\hline 3 & Czerwona & czerwień żelazowa $\mathrm{Fe}_{2} \mathrm{O}_{3}$, cynober $\mathrm{Hg}_{2} \mathrm{~S}_{2}$ kreda $\mathrm{CaCO}_{3}$ & klejowe (kazeina) \\
\hline 2 & Czarna & czerń weglowa, kreda $\mathrm{CaCO}_{3}$ & klejowe (kazeina) \\
\hline 1 & Biała & kreda $\mathrm{CaCO}_{3}$ & klejowe (kazeina) \\
\hline
\end{tabular}

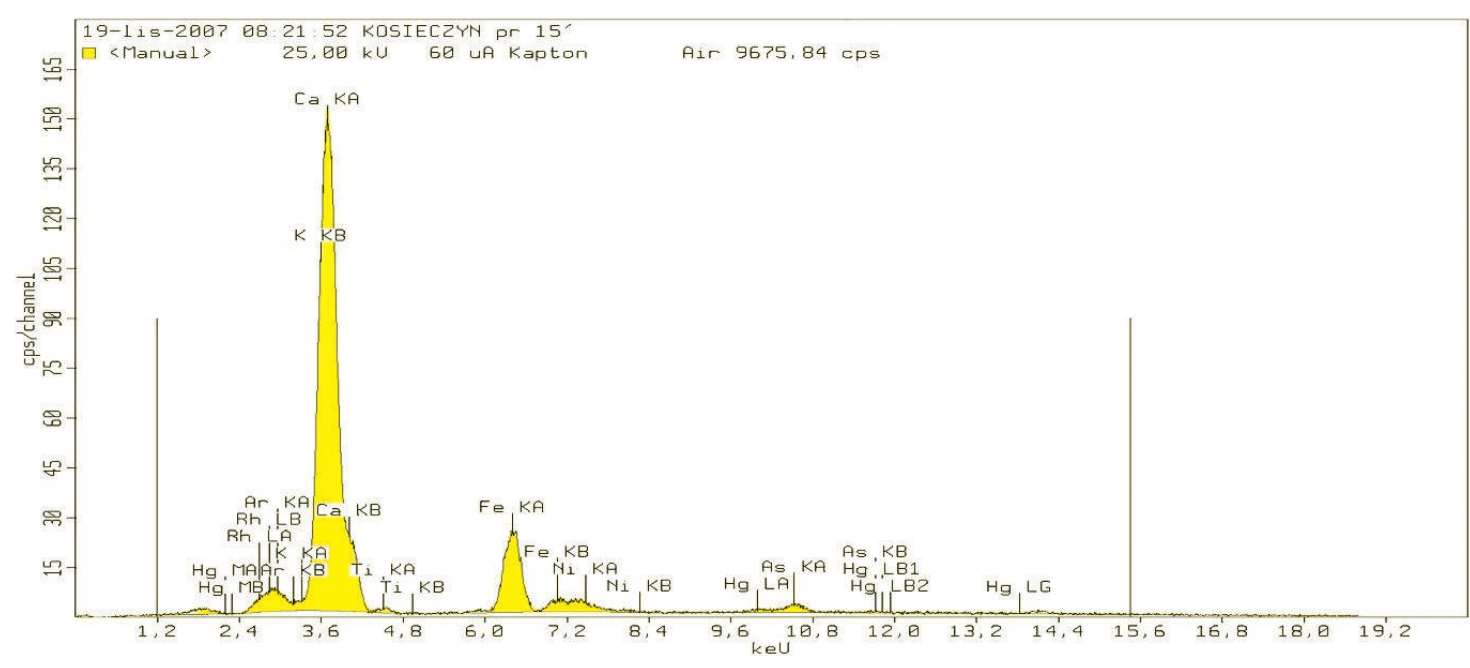

Il. 14. Rentgenowska analiza fluorescencyjna próbki 15’: Ca, Fe, Hg?, As, Ti 


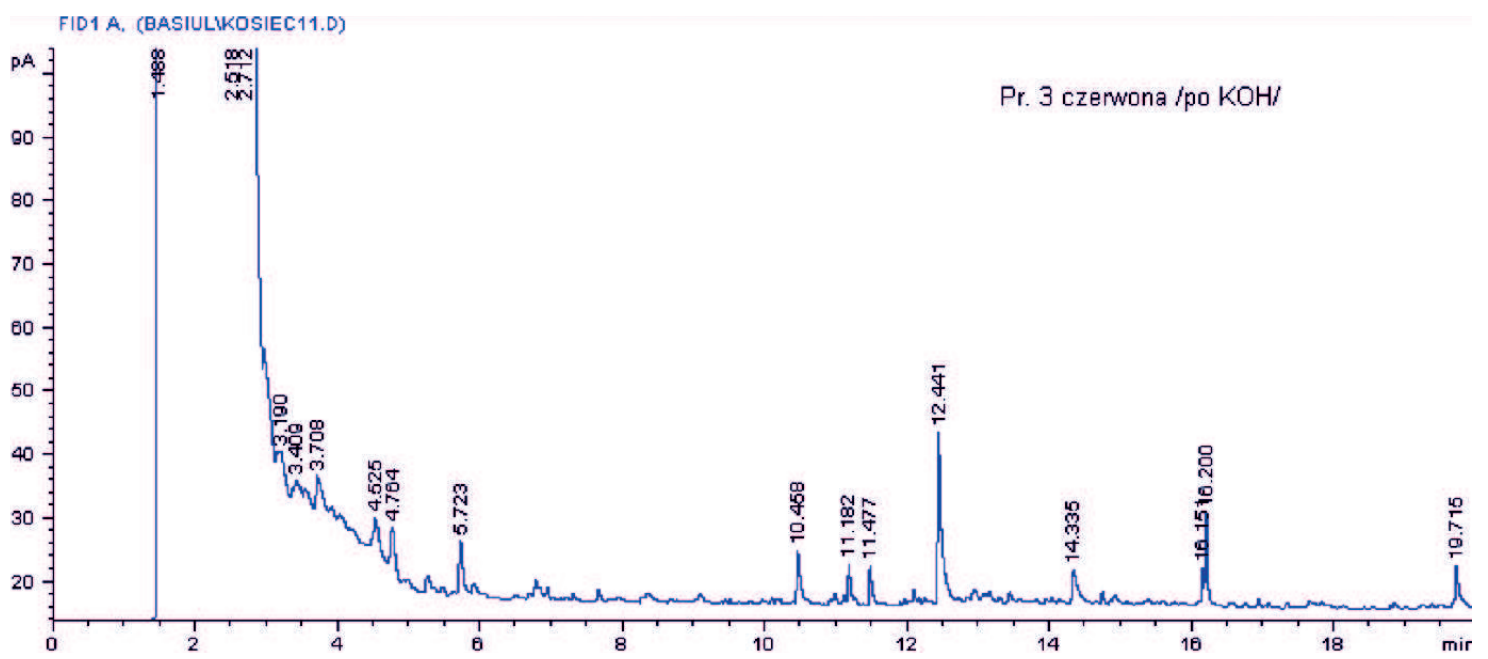

Il. 15. Chromatogram (GC) próbki polichromii z kościoła w Kosieczynie wskazujący na obecność w warstwie mleka zwierzęcego (spoiwo kazeinowe). Badanie wykonał G. Jaworski, Zakład Technologii i Technik Malarskich, IZK, UMK 


\section{Literatura}

Hopliński J., Farby i spoiwa malarskie, Wrocław-Kraków 1959.

Howard H. C., Techniques of Romanesque and Gothic wall paintings in the Holy Sepulchre Chapel, Winchester Cathedral, [w:] Historical Painting Techniques, Materials, and Studio Practice. Preprints of a Symposium University of Leiden, The Netherlands, June 1995, Getty Conservation Institute, Los Angeles 1995, s. $91-104$.

Ligęza M., Rutkowski J., Reflektografia w podczerwieni, „Biuletyn Informacyjny Konserwatorów Dzieł Sztuki”, 1994, t. 5, nr 1-4 (16-19).

Metody badawcze stosowane w identyfikacji i diagnostyce dziet sztuki, pod red. W. Ślesińskiego, „Zeszyty Naukowe ASP w Krakowie”, Kraków 1980, z. 11.

Mirowska E., Poksińska M., Rouba B., Wiśniewska I., Identyfikacja podobrazi i spoiw w zabytkowych dziełach sztuki, Toruń 1992.

Rudniewski P., Pigmenty i ich identyfikacja, Skrypt 13, ASP w Warszawie, Warszawa 1994.

Teofil Prezbiter, Diversarum Artium Schedula. Średniowieczny zbiór przepisów o sztukach rozmaitych, tłum. St. Kobielus, Kraków 1998.

Thompson V. D., The materials and techniques of Medieval Painting, London 1956.

Ważny T., Analiza dendrochronologiczna kościoła w Kosieczynie, „Lubuskie Materiały Konserwatorskie", Zielona Góra 2007, t. 4, s. 42. 


\section{Summary}

\section{Conservation research of mural paintings in the parish church of St. Simon and St. Jude Thaddeus in Kosieczyn}

Conservation research of stratification of plasters and polychromes occurring on inner walls of the parish church St. Simon and St. Jude Thaddeus in Kosieczyn revealed the presence of the oldest painted decoration applied directly on the wooden support. Using the strip-sampling method and thorough examination of samples of later deposits as well as non-destructive analytical techniques a detailed identification of materials making the subsequent chronological strata has been performed. The reconstruction of the chronology of the decoration of the church was the next stage of research, preceded by (among others) the analysis of construction and dendrochronological analysis. The original paintings, occurring beneath the layer of clay coat, have been preserved in small number, mainly on south wall of the presbytery. The discovered decoration consists on vertical stripes with floral motifs. The pigments identified in this paint layer as well as the binder of dairy milk (casein) do not allow for explicit dating of the decoration. Technique of the making of the oldest decoration of the interior of the parish church in Kosieczyn was typical for middle ages, but was used also in later periods. 